\title{
Flipped Learning Berbasis Web Pada Pembelajaran \\ Di Universitas Negeri Padang
}

\author{
Yulhendri \\ Universitas Negeri Padang \\ Tri Kurniawati \\ Universitas Negeri Padang
}

\begin{abstract}
Abstrak
E-Learning merupakan salah satu terobosan dalam bidang pendidikan yang memanfaatkan teknologi informasi. Berbagai model pembelajaran online pun mulai dikembangkan. Misalnya blended learning, distance learning (belajar jarak jauh) dan flipped learning. Pembelajaran online ini pada dasarnya mencoba untuk melakukan inovasi dan perubahan terhadap paradigma dalam pembelajaran. Salah satu model pembelajaran online yang saat ini cukup banyak menjadi kajian dalam penelitian pendidikan adalah flipped learning. Flipped learning adalah pembelajaran yang menggabungkan pertemuan di kelas dengan pembelajaran secara online. Pada flipped learning hal-hal yang biasa dilakukan didalam kelas seperti menjelaskan materi, memberikan tugas, latihan dan tugas rumah di pindahkan menjadi pembelajaran online. Penelitian ini dilakukan dengan desain penelitian pengembangan.
\end{abstract}

\section{Pendahuluan}

\section{Latar Belakang Masalah}

Perkembangan teknologi informasi berjalan begitu cepat dan merambah berbagai aspek kehidupan. Perkembangan ini menjadikan dunia seolah-olah tanpa batas. Teknologi ini dikenal dengan istilah internet. Berbagai informasi, berita, fasilitas bersosial media, fasilitas perdagangan secara online, termasuk pendidikan online atau e-learning, disediakan melalui media internet.

Bishop (2013) menyatakan bahwa bahwa there are two related movement that are combining to change the face of education. The first of these is a technological movement that enabled the amplification and duplication of informatioan at an extremely low-cost. Jadi pendapat ini memberikan pesan penting bahwa kemajuan pendidikan bisa dicapai, salah satunya dan terpenting, melalui pengembangan teknologi. Pemanfaatan teknologi khususnya teknologi informasi bisa memfasilitasi penyampaian informasi secara luas dan menghilangkan batas-batas serta kesulitan ketika pembelajaran hanya mengandalkan tatap muka di kelas. 
E-Learning merupakan salah satu terobosan dalam bidang pendidikan yang memanfaatkan teknologi informasi. Berbagai model pembelajaran online pun mulai dikembangkan. Misalnya blended learning, distance learning (belajar jarak jauh) dan flipped learning (McKnight, 2013). Pembelajaran online ini pada dasarnya mencoba untuk melakukan inovasi dan perubahan terhadap paradigma dalam pembelajaran. Pada kelas-kelas tradisional dosen akan berdiri di depan kelas dan menjelaskan materi kuliah satu persatu. Sementara mahasiswa duduk dan mencatat dengan tenang setiap penjelasan dosennya. Pada akhir perkuliahan mereka diberikan tugas sebagai pekerjaan rumah yang mengharuskan mereka membaca lagi buku literaturnya dan menjawab satu persatu pertanyaan yang diberikan dosen. Begitulah perkuliahan berjalan minggu demi minggu pada jadwal yang telah ditentukan. Dan yang paling disadari oleh dosen adalah banyak materi yang harus dituntaskan setiap pertemuan sampai dengan semester berakhir.

Rutinitas pada kelas-kelas tradisional semacam ini bisa lebih dikembangkan dan diefisienkan dengan memanfaatkan pembelajaran online atau e-learning. Melalui e-learning mahasiswa punya kesempatan untuk belajar di mana saja dan kapan saja selama mereka memiliki akses terhadap jaringan internet. Memang tidak memungkinkan bagi mahasiswa untuk membawa buku kemana-mana. Tapi sangat mungkin bagi mahasiswa untuk membawa perangkan telepon seluler atau smartphone yang mereka punya kemana-mana dan memanfaatkannya untuk belajar kapan saja.

Salah satu model pembelajaran online yang saat ini cukup banyak menjadi kajian dalam penelitian pendidikan adalah flipped learning. Pionir dari flipped learning adalah guru Kimia dari Colorado tahun 2007. Siswa-siswa kimia dikelasnya sering tidak dapat mengikuti pembelajaran di kelas karena harus mengikuti perlombaan, pertandingan dan even lain yang sejenis. Untuk mengantisipasi hal ini kedua guru mengembangkan video untuk merekam pembelajaran, demontrasi, dan slide peresentasi yang ditayangkan. Rekaman ini kemudian di upload di YouTube sehingga siswa dapat mendownloadnya kapan saja dan dimana saja. Kemudian di tahun 2012 didirikanlah sebuah organisasi non profit dengan nama Flipped Learning Network (FLN) yang bertujuan untuk membekali para pendidik dengan pengetahuan, keterampilan dan bahan-bahan untuk dapat mengimplementasikan flipped learning (McKnight, 2013).

Flipped learning adalah pembelajaran yang menggabungkan pertemuan di kelas dengan pembelajaran secara online. Menurut Herreid (2013) dalam flipped learning hal-hal yang biasa dilakukan di dalam kelas seperti menjelaskan materi, memberikan tugas, latihan dan tugas rumah di pindahkan menjadi pembelajaran online. Daripada mahasiswa harus mendengarkan penjelasan dosen tentang pengertian akuntansi, bidang-bidang akuntansi dan sejenisnya lebih baik semuanya direkam dalam video dan mahasiswa diminta menonton video tersebut sebelum perkuliahan berlangsung. Di dalam kelas pembelajaran benar-benar lebih bersifat student centered karena di dalam kelas mahasiswa akan punya lebih banyak waktu untuk menyelesaikan studi kasus, melakukan pembelajaran berbasis masalah, praktik dan berdiskusi. Prinsip dalam dalam flipped learning adalah bahwa hal-hal yang biasanya jadi tugas rumah (seperti latihan, studi kasus, problem solving dan semacamnya) lebih baik dikerjakan di kelas. Sementara mendengarkan penjelasan dosen menjadi tugas rumah dalam bentuk video. Oleh karena itu pembelajaran ini dinamakan flipped learning (Herreid, 2013). 
Studi dan penelitian tentang tentang flipped learning masih terus berkembang. Dari penelitian-penelitian yang dilakukan dapat disimpulkan bahwa persepsi siswa terhadap penerapan flipped learning positif, siswa yang diberi bahan berupa video lebih baik penguasaannya ketimbang disuruh membaca buku teks, mahasiswa sulit untuk menyelesaikan tugas membaca materi dan mahasiswa lebih menyukai video pendek ketimbang yang terlalu panjang (Bishop, 2013, DeGrazia dkk, 2012, Nguyen dkk, 2009, Zappe 2009). Studi oleh Moravec dkk (2010) pada perkuliahan biologi dilakukan melalui pemberian video naratif power point sebelum perkuliahan berlangsung. Hal ini berhasil meningkatkan hasil belajar mahasiswa sebanyak $21 \%$ dalam menguasai konsep-konsep yang ada di video. Sementara studi oleh Roach (2014) pada perkuliahan mikro ekonomi menyatakan flipped learning menghasilkan respon positif dari mahasiswa dan desain pembelajaran yang dirancang bermanfaat bagi mahasiswa. Hasil-hasil penelitian ini memberikan gambaran bahwa flipped learning memberikan pembaharuan positif untuk pengembangan pembelajaran. Di sisi lain, pengembangan pembelajaran yang menstimulasi kemampuan penguasaan materi pembelajaran juga dapat dikembangkan dengan model pembelajaran berbasis riset (Yulhendri, Syofyan, 2018).

Universitas Negeri Padang (UNP) sebagai universitas yang punya visi menjadi world class university juga terus berbenah dalam peningkatan kualitas pembelajarannya. Sejak pendaftaran dilakukan secara online universitas juga makin memfasilitasi dilakukannya pembelajaran berbasis teknologi informasi. Pada awalnya dosen diberikan portal yang memfasilitasi dosen untuk mengupload materi perkuliahan, memberikan tugas-tugas dan bahan kuliah lain. Setelah itu UNP terus mengembangkan fasilitas e-learning dengan fitur-fitur yang semakin lengkap. Ditambah lagi dengan jaringan internet baik kabel maupun nirkabel yang tersedia secara luas. Hal ini memungkinkan bagi seluruh civitas akademika untuk dapat memanfaatkan fasilitas internet. Oleh karena itu pemanfaatan seluruh fasilitas ini perlu terus dioptimalkan utamanya dalam meningkatkan kualitas belajar mengajar. Salah satunya melalui perancangan flipped learning yang peneliti ajukan dalam penelitian ini.

Pengembangan flipped learning direncanakan akan dilaksanakan di Fakultas Ekonomi UNP. Flipped learning direncanakan akan dilaksanakan pada dua mata kuliah yaitu Pengantar Ekonomi Mikro dan Pengantar Akuntansi 2. Dua mata kuliah ini dipilih dengan beberapa pertimbangan. Pertama, mata kuliah ini merupakan mata kuliah dasar dan prasyarat sehingga penguasaan mahasiswa sangat penting untuk dapat mengikuti perkuliahan lebih lanjut seperti Teori Mikro dan Akuntansi Menengah dan Akuntansi Lanjutan. Sementara selama membina mata kuliah ini penulis menemukan tingkat kegagalan mahasiswa masih cukup tinggi. Misalnya di Semester Juli-Desember 2015 ini saja hanya 30\% mahasiswa yang bisa mendapatkan nilai diatas 70 pada ujian tengah semester di perkuliahan Pengantar Akuntansi 2. Hal ini tidak jauh berbeda dengan kondisi di perkuliahan Pengantar Ekonomi Mikro. Kedua, materi diperkuliahan ini juga cukup padat. Jika konten materi dikurangi maka learning outcome tidak bisa dicapai. Namun jika sks ditambah juga tidak sejalan dengan tuntutan total sks sesuai kurikulum. Hal ini selalu menjadi dilema. Latihan lebih banyak dikerjakan mahasiswa di rumah. Pertemuan tatap muka banyak dihabiskan untuk ceramah dan tanya jawab. Materi yang disusun setiap minggu sangat membatasi dosen untuk bisa membahas 
banyak latihan dikelas. Apalagi jika tidak diberikan penjelasan materi secara ceramah mahasiswa sering salah memahami materi dan isi buku teks. Hal ini juga mungkin terkait dengan kemampuan dan kemauan mereka untuk membaca dengan baik masih relatif terbatas.

Dengan segala kendala ini maka implementasi flipped learning penulis rasa menjadi salah satu solusi berharga untuk meningkatkan kualitas pembelajaran di Fakultas Ekonomi UNP khususnya pada dua mata kuliah tersebut. Penelitian ini direncanakan akan dilaksanakan selama 2 tahun. Tahun pertama digunakan untuk merancang perangkat-perangkat pembelajaran yang dibutuhkan baik itu video untuk setiap materi dan pertemuan, materi diskusi, kasus, latihan dan praktik di kelas, evaluasi dan instrumen lain yang terkait. Sementara pada tahun kedua direncanakan akan dilaksanakan ujicoba melalui penelitian dengan pendekatan quasi-eksperimen. Penelitian ini berjudul Pengembangan Flipped Learning Berbasis Web pada Pembelajaran di Universitas Negeri Padang.

\section{Rumusan Masalah}

Berdasarkan latar belakang di atas maka rumusan masalah dalam penelitian ini adalah:

1. Bagaimanakah model perangkat pembelajaran untuk pengimplementasian flipped learning pada perkuliahan Pengantar Akuntansi 2 dan Pengantar Ekonomi Mikro di FE UNP?

2. Bagaimana persepsi mahasiswa terhadap tampilan Website Pembelajaran yang telah dirancang

3. Bagaimana persepsi mahasiswa tentang materi dan konten pembelajaran ekonomi mikro dan pengantar akuntansi 2

\section{Kajian Teori}

\section{Belajar dan Hasil Belajar}

Belajar merupakan sebuah proses yang kompleks. Menurut Hilgrad dan Bower (dalam Baharudin, 2007) belajar (to learn) memiliki arti: to gain knowledge, comprehension, or mastery of through experience or study, to fis in the mind or memory, memorize, to acquire through experience and to become in form of to find out. Menurut defenisi tersebut belajar memiliki pengertian memperoleh pengetahuan atau menguasai pengetahuan melalui pengalaman, dan mendapatkan informasi atau menemukan. Dengan demikian belajar memiliki arti dasar adanya aktivitas atau kegiatan dan penguasaan tentang sesuatu.

Selanjutnya, hasil belajar merupakan gambaran pencapaian tujuan pembelajaran oleh peserta didik yang diperoleh melalui proses evaluasi hasil belajar secara sistematis dan terencana. Menurut Gronlund (1976) evaluation may be defined as a systematic process of determining the extent to which instructional objectives are are achieved by pupils. Dari pengertian di atas terdapat dua aspek penting dalam evaluasi hasil belajar. Pertama, evaluasi merupakan proses penentuan ketercapaian tujuan pembelajaran. Kedua, tujuan pembelajaran harus ditentukan terlebih dahulu karena akan menjadi dasar penentuan keberhasilan peserta didik dalam proses belajar. 
Proses belajar dan hasil belajar merupakan dua hal yang terpisah. Dari proses belajar akan tampak hasil belajar berupa kemampuan atau "performance" dari peserta didik. Gronlund (1976) menyatakan bahwa hasil belajar adalah any measurable, or observable pupil response in the cognitive, affective, or psychomotor area that is a result of learning.

Senada dengan pendapat Gronlund di atas, kemampuan yang diperoleh individu dari proses pembelajaran menurut Bloom dapat dikategorikan kepada tiga ranah yaitu kognitif, afektif dan psikomotor (Sudjana, 2003). Ketiga ranah ini dapat dijelaskan sebagai berikut:

1. kemampuan kognitif adalah ranah yang mencakup kegiatan otak. Dalam ranah kognitif terdapat enam jenjang proses berpikir mulai dari yang terendah sampai dengan jenjang yang paling tinggi. Pertama adalah pengetahuan yaitu kemampuan untuk mengingat kembali apa yang telah dipelajari. Kedua adalah pemahaman yaitu kemampuan seseorang untuk mengerti atau memahami sesuatu setelah sesuatu itu di ketahui dan diingat. Ketiga, penerapan yaitu kemampuan seseorang untuk menerapkan atau menggunakan ide-ide umum, tata cara atau pun metode-metode, teori dan sebagainya dalam situasi baru dan konkret. Keempat, analisis yaitu kemampuan untuk merinci atau menguraikan suatu bahan atau keadaan menjadi bagian-bagian yang lebih kecil dan mampu memahami keterkaitannya satu sama lain. Kelima, sintesis yaitu kemampuan untuk memadukan bagian-bagian atau unsur-unsur secara logis sehingga menjadi suatu pola yang berstruktur. Dan keenam adalah evaluasi, yaitu kemampuan seseorang untuk dapat membuat pertimbangan atas suatu situasi, nilai atau ide dan kemudian memilih satu pilihan yang terbaik.

2. kemampuan afektif terkait dengan sikap dan nilai. Ranah afektif dibagi menjadi lima jenjang. Pertama receiving yaitu kepekaan seseorang dalam menerima rangsangan dari luar yang datang kepada dirinya. Kedua responding yaitu kemampuan untuk menanggapi sehingga ada partisipasi aktif. Ketiga valuing yaitu memberikan penghargaan atau nilai terhadap suatu kegiatan atau objek sehingga apabila tidak dilaksanakan dirasakan akan membawa kerugian atau penyesalan. Keempat organization artinya mempertemukan perbedaan nilai sehingga terbentuk nilai baru yang lebih universal yang membawa kepada perbaikan umum. Dan kelima adalah characterization by a value yaitu keterpaduan semua sistem nilai yang telah dimiliki seseorang yang mempengaruhi kepribadian dan tingkah lakunya.

3. Kemampuan psikomotor adalah kemampuan yang berkaitan dengan keterampilan atau kemampuan bertindak setelah seseorang menerima pengalaman belajar tertentu. Hasil belajar psikomotor ini merupakan kelanjutan dari hasil belajar kognitif dan afektif. Hasil belajar kognitif dan afektif akan menjadi hasil belajar psikomotor apabila peserta didik telah menunjukkan perilaku atau perbuatan tertentu sesuai dengan makna yang terkandung dalam ranah kognitif dan afektifnya.

Jadi, hasil belajar merupakan kemampuan, pengetahuan dan skill yang dimiliki peserta didik setelah melalui proses pembelajaran yang dapat dikategorikan kepada ranah kognitif, afektif dan psikomotor. Hasil belajar yang dicapai akan tergambar dalam indeks prestasi ataupun nilai yang diperoleh oleh peserta didik atau mahasiswa. Hal ini sesuai dengan pendapat Rinn (2007) bahwa 
academic achievement can be measured by asking students to report their current, cumulative grade point average, which could range from 0.00 to 4.00 .

\section{Faktor-Faktor yang Mempengaruhi Hasil Belajar.}

Hasil belajar yang diperoleh oleh peserta didik merupakan hasil interaksi dengan berbagai faktor yang mempengaruhinya baik faktor dari dalam individu maupun dari luar. Baharudin (2007) dan Slameto (2003) membagi faktor yang mempengaruhi prestasi belajar peserta didik atas faktor internal dan faktor eksternal. Faktor internal merupakan faktor yang berasal dari dalam diri individu yang mempengaruhi prestasi belajarnya. Faktor tersebut antara lain faktor fisiologis dan faktor psikologis. Sedangkan faktor eksternal merupakan faktor yang berada di luar diri individu. Diantara faktor eksternal tersebut adalah faktor sekolah, faktor keluarga dan faktor masyarakat. Pada faktor sekolah terdapat faktor kurikulum, metode mengajar, interasi antara guru dan siswa serta siswa dengan siswa, disiplin sekolah, media pembelajaran, waktu sekolah, fasilitas sekolah dan lain sebagainya.

Sementara Purwanto (2007) membagi faktor yang mempengaruhi proses dan hasil belajar di sekolah menjadi dua faktor yaitu instrumental input dan environmental input. Environmental input adalah masukan yang ada pada lingkungan sementara instrumental input adalah faktor yang sengaja dirancang dan dimanipulasi guna menunjang tercapainya hasil yang dikehendaki. Instrumental input ini meliputi kurikulum, guru yang memberikan pengajaran, sarana dan fasilitas, serta manajemen yang berlaku di sekolah yang bersangkutan.

Pembelajaran yang ditunjang dengan implementasi model pembelajaran yang menstimulasi kemampuan berpikir tingkat tinggi siswa salah satunya yaitu research based learning (Of \& On, 2018)Yulhendri,

Dalam penelitian ini peningkatan hasil belajar mahasiswa akan dilakukan melalui pengelolaan faktor ekternal yaitu faktor instrumental yang dirancang melalui flipped learning. Flipped learning akan memberikan pengalaman belajar yang jauh lebih fleksibel kepada mahasiswa. Selain itu kegiatan belajar mengajar di kelas dapat dimanfaatkan secara lebih optimal untuk meningkatkan aktifitas belajar mahasiswa.

\section{A. Flipped Learning}

Flipped learning merupakan salah satu bentuk pembelajaran yang memanfaatkan teknologi informasi. Menurut McKnight (2013:4):

In the flipped learning model, teachers shift direct learning out of the large group learning space and move it into the learning space, with the help of one of several technologies. Teachers record narrate screencasts of work they do on their computer desktops, create videos of themselves teachinng, or curate video lesson from internet sites such as TED-Ed and Khan Academy. ...enabling student to come to class better prepared.

Dari pengertian di atas terlihat bahwa flipped learning adalah model pembelajaran yang mengkombinasikan pembelajaran online dengan pembelajaran tatap muka. Pembelajaran online dimaksudkan untuk memberikan materi dan penjelasan serta memberikan tugas-tugas untuk nantinya dikerjakan dalam kelas tatap muka. Pada pembelajaran tatap muka dilakukan pembahasan tugas, studi 
kasus ataupun problem solving yang intinya mengaktifkan siswa dan memberikan pengalaman belajar secara luas. Pembelajaran ini juga lebih efektif karena materi kuliah dapat diakses mahasiswa kapan saja dan dimana saja melalui fasilitas internet.

Hal ini berbeda dengan pembelajaran jarak jauh (distance learning) yang membuat tatap muka dilakukan melalui media teleconference. Pembelajaran pada dasarnya tetap tatap muka namun dosen dan mahasiswa berada ditempat yang berbeda. Flipped learning juga berbeda dengan blended learning yang mengkombinasikan metode pembelajaran tatap muka dengan online learning. Metode pembelajaran bisa berupa tatap muka sehari-hari, kemudian ada beberapa komponen pembelajaran e-learning yang disisipkan, maupun sebaliknya, kebanyakan pembelajaran e-learning, lalu disisipkan metode tatap muka. Model flipped learning dapat dilihat pada gambar di bawah ini:

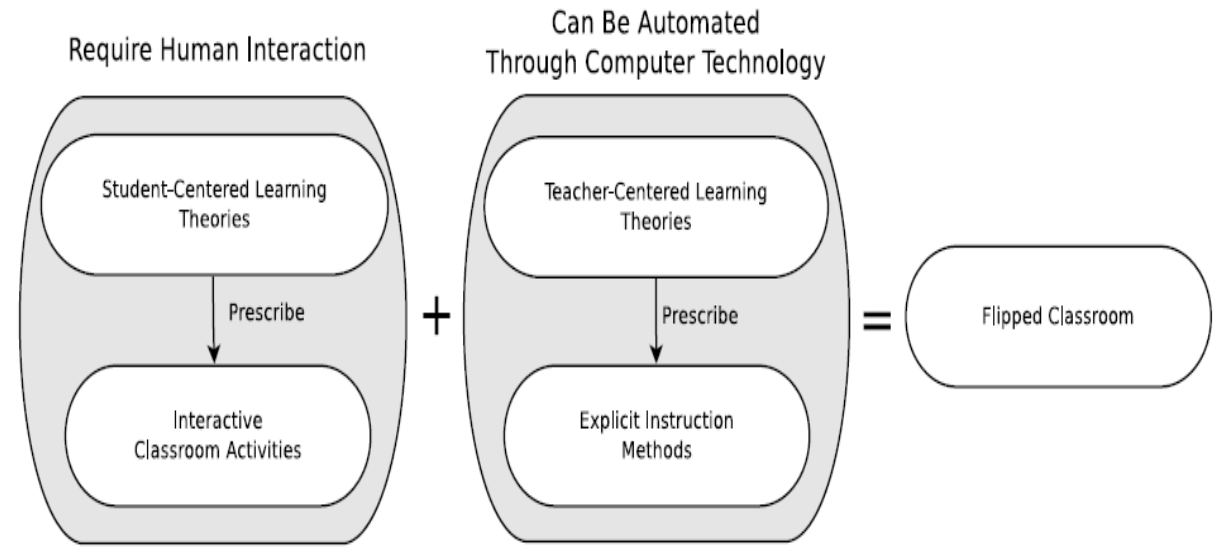

Gambar 1. Flipped Classroom (Bishop, 2013)

Fulton dalam Herreid (2013) menyatakan beberapa keunggulan penggunaan flipped learning. Keuntungan tersebut yaitu: 1) siswa dapat berkembang sesuai kecepatan masing-masing, 2) melakukan latihan yang biasanya menjadi PR di dalam kelas memberikan gambaran yang lebih baik kepada pendidik tentang gaya belajar berikut juga kesulitan belajar siswa, 3) waktu tatap muka dapat dimanfaatkan secara lebih efektif dan kreatif, 4) guru dapat lebih mudah menilai prestasi, minat dan komitmen belajar siswa, 5) penggunaan teknologi membuat pembelajaran lebih fleksibel dan cocok untuk pembelajaran di abad 21.

\section{METODE PENELITIAN}

Desain penelitian pengembangan (Research and Development, R\&D). Penelitian pengembangan merupakan kegiatan pengumpulan, pengolahan, analisis, dan penyajian data yang dilakukan secara sistematis dan objektif yang disertai dengan kegiatan mengembangkan suatu produk untuk memecahkan suatu persoalan yang dihadapi. Sugiyono (2012) menyatakan bahwa penelitian 
pengembangan merupakan metode penelitian yang digunakan untuk menghasilkan produk tertentu dan menguji keefektifan produk tersebut.

Penelitian ini dilakukan dengan beberapa prosedur. Prosedur tersebut meliputi tahap perencanaan, eksplorasi, pengembangan awal produk, validasi dan revisi akhir. Tahap pertama adalah perencanaan yang meliputi penyusunan dan persiapan langkah-langkah penelitian pengembangan perangkat pembelajaran flipped learning untuk perkuliahan pengantar akuntansi 2 dan pengantar ekonomi mikro. Tahap kedua adalah eksplorasi. Tahap eksplorasi meliputi kajian literatur, studi dokumen dan studi lapangan. Eksplorasi akan juga akan dilakukan terhadap video-video pembelajaran yang dikeluarkan oleh kementrian pendidikan dan juga website seperti TED-Ed dan Khan Academy untuk mendapatkan video yang relevan dengan pembelajaran yang dilakukan. Situs-situs ini menyediakan berbagai video pembelajaran pada berbagai disiplin ilmu.

Tahap ketiga pengembangan awal produk, berupa revisi silabus (jika diperlukan) pembuatan Satuan Acara Perkuliahan (SAP), materi video pembelajaran, rancangan tugas, kasus, latihan dan masalah untuk didiskusikan dalam kelas berikut model pembelajaran yang akan diterapkan. Penyusunan perangkat pembelajaran ini akan dilakukan dengan melibatkan tim dosen pengampu mata kuliah, dosen strategi pembelajaran ekonomi dan juga tim ahli IT. Tim ahli IT akan dibutuhkan untuk memberikan masukan tentang proses upload video pembelajaran untuk dapat di download dari internet.

Pada tahap keempat akan dilakukan validasi dan revisi produk. Tahap validasi meliputi uji pakar dan uji coba. Kegiatan validasi pertama yaitu validasi teoritis yang ditempuh melalui pemeriksaan pakar atau panelis yang menilai perangkat pembelajaran yang telah disusun. Langkah ini dilakukan dengan menggunakan Focus Group Discussion (FGD) dengan dosen pengampu mata kuliah, dosen strategi pembelajaran dan juga tim ahli IT seperti dipaparkan sebelumnya. Selain itu juga akan dilibatkan beberapa mahasiswa untuk melihat tanggapan awal mahasiswa terhadap model pembelajaran yang dirancang tim.

Hasil perangkat pembelajaran yang telah melewati validasi teoritis dengan uji pakar akan dilanjutkan dengan proses ujicoba untuk mendapatkan validasi empirik. Ujicoba dilakukan dengan model penelitian quasi eksperimen. Hal ini akan dilakukan pada tahun kedua penelitian ini. Pada penelitian eksperimen akan dibandingkan persepsi, aktifitas dan hasil belajar mahasiswa yang menggunakan flipped learning dengan yang tidak menggunakan flipped learning pada perkuliahan pengantar akuntansi 2 dan pengantar ekonomi mikro. Bagan alir proses penelitian dapat dilihat pada gambar berikut ini.

\section{Metoda Pengumpulan Data}

Pengumpulan data dalam penelitian ini akan dilakukan dengan studi dokumentasi, studi literatur dan FGD untuk tahun pertama. Untuk tahun kedua digunakan angket untuk mengungkapkan persepsi mahasiswa terhadap pembelajaran yang berlangsung, daftar checklist dan catatan lapangan untuk mengamati aktifitas belajar mahasiswa serta tes untuk mengevaluasi hasil belajar mahasiswa.

\section{A. Teknik Analisis Data}


Untuk kepentingan analisis data penelitian, setiap prosedur penelitian akan dilakukan dengan teknik analisis data yang berbeda-beda. Teknik analisis data dalam penelitian ini dapat dijelaskan sebagai berikut:

1. Pada tahun pertama hasil FGD dan produk yang dirancang akan dipaparkan secara deskriptif. Analisis data yang digunakan lebih kepada teknik analisis deskriptif.

2. Pada tahun kedua untuk membedakan aktifitas dan hasil belajar mahasiswa antara kelas kontrol (tanpa flipped learning) dengan kelas eksperimen (menggunakan flipped learning) akan dilakukan analisis statistik dengan uji beda dua rata-rata. Untuk proses analisis data juga akan digunakan progam statistik SPSS for Windows.

\section{Hasil dan Luaran}

Proses penelitian ini telah dilakukan semenjak bulan Mei 2016 sejalan dengan penandatanganan kontrak penelitian. Sampai saat ini penelitian telah sampai pada proses penyusunan seluruh perangkat pembelajaran untuk mata kuliah pengantar ekonomi makro dan pengantar akuntansi 2 yang akan diimplementasikan pada flipped learning. Perangkat ini berupa silabus, satuan acara perkuliahan (SAP), bahan ajar, media power point, soal dan lembar jawaban quiz. Perangkat ini masih dalam proses penyempurnaan bersama tim mata kuliah.

Sampai saat ini penelitian diperkirakan baru mencapai tahap $40 \%$. Keterlambatan ini terjadi karena sampai dengan laporan kemajuan disusun, dana penelitian belum juga dicairkan sehingga agak menyulitkan bagi tim peneliti untuk dapat segera menyelesaikan seluruh tahapan penelitian. Luaran penelitian yang dapat dihasilkan sampai proses laporan kemajuan ini disusun belum final. Penelitian ini direncanakan akan diseminarkan pada International Conference on Economics, Business and Accounting (ICEBA) 2016.

\section{Simpulan dan Saran}

Dari pemaparan yang telah diungkapkan pada bab-bab sebelumnya, maka dapat disimpulkan:

1. Proses penelitian ini baru sampai pada proses pengembangan instrumen dan perangkat pembelajaran untuk mata kuliah pengantar ekonomi makro dan pengantar akuntansi 2 .

2. Hasil penelitian ini direncanakan akan diseminasikan pada ICEBA 2016.

\section{Saran}

Banyak faktor yang akan mempengaruhi pelaksanaan penelitian. Walaupun penelitian ini dijadwalkan selama satu tahun tapi waktu efektif penelitian sangat singkat dan cukup menyulitkan bagi peneliti untuk dapat melaksanakan seluruh tahapan penelitian secara baik dan optimal. Belum lagi keterlambatan dari segi pendanaan. Untuk itu disarankan untuk penelitian-penelitian tahun berikutnya jangka waktu efektif penelitian dapat lebih diperpanjang dan administrasi penelitian seperti pengumuman hasil seleksi, penandatanganan kontrak dan pencairan dana dapat lebih dipercepat agar penelitian yang dihasilkan semakin baik dan optimal. 


\section{DAFTAR PUSTAKA}

Baharudin dan Esa Nur Wahyuni. 2007. Teori Belajar dan Pembelajaran. Yogyakarta: Ar- Ruz Media.

Bishop, Jacob Lowell \& Matthew A Verleger. 2013. The Flipped Classroom: A Survey of Research. Prosiding pada 120th ASEE Conference \& Exposition, 23-26 Juni 2015.

Gronlund, Norman E. 1976. Measurement and Evaluation in Teaching. New York: Macmillan Publisher.

Herreid, Freeman \& Nancy A Schiller. 2013. Case Studies and The Flipped Classroom. Journal of College Science Teaching Vol. 42, No. 5,hal 63-66.

DeGrazia, Janet L, John L. Falconer, Garret Nicodemus, and Will Medlin. 2012 Incorporating Screencasts into Chemical Engineering Courses. In Proceedings of the ASEE Annual Conference \& Exposition, 2012

Mcknight, Patrick dkk. 2003. A Review of Flipped Learning. USA: Pearson.

Moravec, A. Williams, N. 2010. Aguilar-Roca, and D.K. O'Dowd. Learn Before Lecture: A Strategy That Improves Learning Outcomes In A Large Introductory Biology Class. CBE-Life Sciences Education, 9(4):473-481, 2010

Nguyen, H \& R. Toto. Flipping The Work Design In An Industrial Engineering Course. In Frontiers in Education Conference, 2009. FIE 2009. 39th IEEE, pages 1-4. IEEE, 2009

Purwanto, M. Ngalim. 2007. Psikologi Pendidikan. Bandung : Remadja Rosdakarya Offset.

Rinn, Anne N. 2007. Effect of Programatic Selectivity on The Academic Self Concept, and Aspirations of Gifted College Student. Jounal of Gifted Child Quarterly. Vol 51. No. 3.

Roach, Travis. 2014. Student perceptions toward flipped learning: New methods to increase interaction and active learning in economics. International Review on Economics Education. Vol. 17 hal: 74-84. 
Slameto. 2003. Belajar dan Faktor-Faktor yang Mempengaruhinya. Jakarta: Rineka Cipta.

Sudjana, Nana. 2003. Penilaian Hasil Proses Belajar Mengajar. Bandung : PT. Remaja Rosdakarya.

Sugiyono. 2012. Metode Penelitian Pendidikan: Pendekatan Kuantitatif, Kualitatif dan R\&D. Bandung Alfabeta.

Yulhendri, Syofyan, A. (2018). DEVELOPMENT RESEARCH-BASED

LEARNING MODEL AND JOURNAL AS FOR GRADUATE STUDENTS

' SCIENTIFIC PUBLICATIONS OF, 8(4), 1-5.

https://doi.org/10.29322/IJSRP.8.4.2018.p76XX

Zappe, Sarah, Robert Lieicht, John Messner, Thomas Litzinger, and Hyeon Woo Lee. 2009. "Flipping" The Classroom To Explore Active Learning in A Large Undergraduate Course. In Proceedings, American Society for Engineering Education Annual Conference \& Exposition, 2009. 